\title{
ACUTE MESENTERIC ISCHEMIA: CASE REPORT
}

\author{
Deimantė Bajoriūnaitė', Justinas Balčiūnas ${ }^{1}$, Deividas Vaiciukevičius ${ }^{2}$, \\ Monika Jasinskaité ${ }^{1}$, Antanas Montvila ${ }^{2}$ \\ ${ }^{1}$ Lithuanian University of Health Sciences, Academy of Medicine, \\ ${ }^{2}$ Lithuanian University of Health Sciences Kaunas Clinics, Department of Radiology
}

Keywords: acute mesenteric ischemia, superior mesenteric artery, intestine ischemia, mesenteric thrombosis.

\begin{abstract}
Summary
Acute mesenteric ischemia (AMI) is a rare cause for hospital admissions of abdominal pain with incidence of less than $0.1 \%$ but due to delay in diagnosis results in a high $40 \%$ to $80 \%$ mortality rate. Small intestine ischemia occurs due to blood supply interruption of the superior mesenteric artery (SMA) which can happen due to embolism, arterial or venous thrombosis or non occlusive ischemia. AMI is most commonly caused by SMA thrombosis, which is precipitated by dehydration, low cardiac output and hypercoagulation, or SMA embolic occlusion, which mostly occurs due to acute myocardial infarction. We present a 74-year-old man who complained of acute chest pain and pressure, black stools that started 4 hours ago. The patient had a history of prostatic hyperplasia and aortic surgery complicated by intestinal necrosis. Computed tomography (CT) showed bleeding in the duodenum, which was stopped using adrenaline. Coronary angiography was performed after cessation of bleeding. The patient began to complain of severe abdominal pain. Abdominal and pelvic contrast CT showed SMA thrombosis. The patient underwent small intestine resection, ileostomy and cystostomy. Histopathological examination revealed ischemic and necrotic changes. Despite the treatment the patient died. Physicians should be aware of AMI as a possible cause of abdominal pain, especially in elderly patients with cardiovascular comorbidities. Contrast enhanced CT should be the first-line imaging modality for differential diagnosis. Thorough assessment of symptoms and risks, timely use of diagnostic and interventional measures can help to reduce high mortality.
\end{abstract}

\section{Introduction}

Acute mesenteric ischemia (AMI) is a rare reason for hospital admissions of abdominal pain with an incidence of less than $0.1 \%$, but due to delay in diagnosis results in a very high $40-80 \%$ mortality rate $[1,2]$. Etiology of small intestine ischemia is categorized into four main categories: mesenteric arterial embolism, mesenteric arterial thrombosis, mesenteric venous thrombosis and nonoclusive mesenteric ischemia [3]. Small intestine ischemia occurs due to blood supply interruption of the superior mesenteric artery (SMA), which supplies blood to the small intestine and the large intestine up to the splenic flexure [4]. AMI is most commonly caused by SMA thrombosis, which is precipitated by dehydration, low cardiac output and hypercoagulation, or SMA embolic occlusion, which mostly occurs due to acute myocardial infarction [5]. Patients experiencing mesenteric ischemia most often present with sudden and severe abdominal pain [6]. Although clinically bowel ischemia symptoms are nonspecific, contrast-enhanced computed tomography (CT) findings can be the cornerstone for AMI diagnosis [7]. If intestinal necrosis has not yet developed, patients can be treated without open surgery, using thrombolytic therapy, balloon dilatation, stent implantation or other appropriate strategies. However, if intestinal necrosis or peritonitis has already developed, open laparotomy is indicated $[8,9,10]$. This report presents a case of a patient with AMI due to thrombosis of SMA.

\section{Case report}

A 71-year old male patient presented to the emergency department in November 2020. The patient was complaining of acute chest pain and tightness that started 4 hours ago. The patient also reported that on the day before the visit stools in his stoma were black. He had a history of prostate hyperplasia, aorta operation with complications - intestine necrosis and stoma. The patient was using aspirin, pentoxifylline 
and other medications which he could not remember.

Upon arrival patients' blood pressure was $97 / 62 \mathrm{mmHg}$, and pulse rate - 115 beats per minute, other vital signs were normal and stable. ECG demonstrated $\mathrm{T}$ inversion and ST depression $\sim 1 \mathrm{~mm}$ in I, aVL, V46. A Serological test showed anemia with hemoglobin $66 \mathrm{~g} / 1$ (the previous test showed $85 \mathrm{~g} / 1$ ), leukocytosis, increased C-reactive peptide (CRP), and high sensitivity troponin $-0,71 \mathrm{mcg} / \mathrm{l}$. The cardiologist decided to postpone coronary artery angiography (CAA) until bleeding from the gastrointestinal tract is stopped. CT showed bleeding to the duodenum. During esophagogastroduodenoscopy (EGD) bleeding from duodenal ulcer was found and stopped using adrenaline, chronic ulcers in the stomach and duodenum were observed. After anemia was stabilized it was decided to perform CAA because troponin kept increasing although chest pain disappeared. After CAA troponin, CRP and hemoglobin decreased. No active gastrointestinal tract bleeding was found during CT. The patient was treated for hemorrhaging shock; hemoglobin increased up to $85 \mathrm{~g} / 1$, but neutrophilic leukocytosis and elevated CRP remained.

After 10 days from hospitalisation the patient started to complain of severe abdominal pain. CT angiography of abdomen and pelvis demonstrated small intestine ischemia, signs of pneumatosis, air inserts in the portal venous system, severe SMA stenosis. Mesenteric infiltration, intraabdominal fluid near liver $\sim 2 \mathrm{~cm}$, near spleen $1,8 \mathrm{~cm}$, in pelvic region $\sim 4 \mathrm{~cm}$, between intestines and in lateral pockets $\sim 2 \mathrm{~cm}$ (Figure 1).

Because of the severe patient's condition, it was decided to prepare the patient for operation. The patient underwent small intestine resection, ileostomy and cystostomy. During operation $1 \mathrm{~m}$ from the Treitz ligament, $50 \mathrm{~cm}$ of small intestine with necrosis and total peritonitis was found. SMA thrombosis was diagnosed during the operation. The histopathological examination demonstrated severe ischemic and necrotic changes.

Sadly, despite the treatment, the patient's state was critical and after unsuccessful resuscitation, he passed away.

\section{Discussion}

Although AMI has a low overall incidence rate, in elderly patients it is a more common reason for abdominal pain than appendicitis or ruptured abdominal aortic aneurysm [11]. Thrombosis of mesenteric arteries is responsible for around 25\% of all AMI incidents, and for patients over 70 years old it is the main cause of AMI. Atherosclerotic disease, dyslipidemia, hypertension, dehydration are the main causes for mesenteric artery thrombosis. Atherosclerotic changes are usually present in other regions such as the heart, brain or other peripheral arteries $[12,13]$. Usually, an early symptom is severe pain in the periumbilical area which diffuses to the whole abdomen and is more intense than physical examination findings would suggest [14]. Progression of pain might be slower in patients with SMA thrombosis as they usually have collateral anastomoses [14,15]. Nausea, vomiting, abdominal distension, diarrhea, gastrointestinal bleeding, tachycardia, tachypnoea and fever are associated with AMI, however, they are nonspecific symptoms and common for all abdominal diseases [16]. Recommended laboratory tests include leukocyte count, procalcitonin, base excess, D-dimer, lactate levels, intestinal fatty acid binding protein and alpha-glutathione S-transferase, but none of them can diagnose AMI in early stages [17]. Early diagnosis raises the survivability of the patient, therefore, early contrast-enhanced CT can be life saving for patients with AMI. Radiological signs of the ischemic injury of intestines include: intestinal wall thickening due to edema or thinning due to distention, decrease of intestinal walls' enhancement due to blood flow interruption, dilated

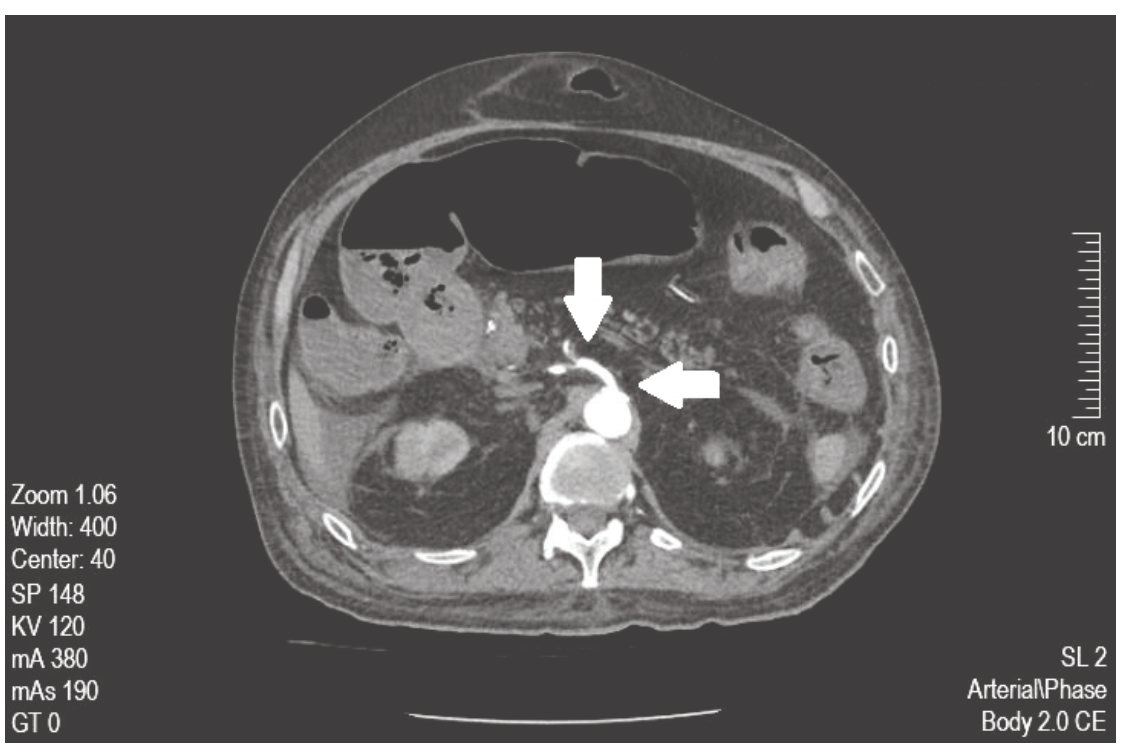

Figure 1. Arterial phase of contrast enhanced CT scan of abdomen and pelvis (transverse view), showing stenosis of superior mesenteric artery. 
fluid filled intestinal loops, which could be confused with mechanical obstruction. Furthermore, pneumatosis, portal venous gas, emboli and thrombi can be observed $[18,19]$. When diagnosed a patient should receive fluid resuscitation, correction of electrolyte abnormalities, broad-spectrum antibiotics and stomach decompression should be initiated. If not contraindicated patients should receive unfractionated heparin. Patients without intestinal necrosis or with partial occlusion of arteries should receive endovascular revascularization procedures. Open laparotomy is indicated to patients with peritonitis and intestinal necrosis due to resection necessity [20-22].

\section{Conclusions}

Physicians should be aware of AMI as a possible cause of abdominal pain, especially in elderly patients with cardiovascular comorbidities. Contrast enhanced CT should be the first-line imaging modality for differential diagnosis. Management of SMA is focused on resection of the necrotic intestine and restoration of blood flow with use of an endovascular or surgical approach. Appropriate awareness of symptoms and risk factors, targeted use of diagnostics and interventions may reduce the high mortality rates of AMI.

\section{References}

1. Lim S, Halandras PM, Bechara C, Aulivola B, Crisostomo P. Contemporary Management of Acute Mesenteric Ischemia in the Endovascular Era. Vasc Endovascular Surg 2019;53(1):4250 .

https://doi.org/10.1177/1538574418805228

2. Monita MM, Gonzalez L. Acute Mesenteric Ischemia. In: StatPearls. Treasure Island (FL): StatPearls Publishing 2020.

3. Amini A, Nagalli S. Bowel Ischemia. StatPearls Publishing 2020.

4. Shaikh H, Wehrle CJ, Khorasani-Zadeh A. Anatomy, Abdomen and Pelvis, Superior Mesenteric Artery. StatPearls Publishing 2020.

5. Acosta S. Mesenteric ischemia. Curr Opin Crit Care 2015;21(2):171-178.

https://doi.org/10.1097/MCC.0000000000000189

6. Kerzmann A, Haumann A, Boesmans E, Detry O, Defraigne JO. L'ischémie mésentérique aiguë [Acute mesenteric ischemia]. Rev Med Liege 2018;73(5-6):300-303.

7. Dhatt HS, Behr SC, Miracle A, Wang ZJ, Yeh BM. Radiological Evaluation of Bowel Ischemia. Radiol Clin North Am 2015;53(6):1241-1254.

https://doi.org/10.1016/j.rcl.2015.06.009

8. Zhuang X, Chen F, Zhou Q, Zhu Y, Yang X. A rapid preliminary prediction model for intestinal necrosis in acute mesenteric ischemia: a retrospective study. BMC Gastroenterol 2021;21(1):154.

https://doi.org/10.1186/s12876-021-01746-0
9. Nuzzo A, Huguet A, Corcos O. Prise en charge moderne des ischémies mésentériques [Modern treatment of mesenteric ischemia]. Presse Med 2018;47(6):519-530.

https://doi.org/10.1016/j.lpm.2018.03.019

10. Orihashi K. Mesenteric ischemia in acute aortic dissection. Gen Thorac Cardiovasc Surg 2018;66(10):557-564. https:/doi.org/10.1007/s11748-018-0970-6

11. Kärkkäinen JM, Lehtimäki TT, Manninen H, Paajanen H. Acute Mesenteric Ischemia Is a More Common Cause than Expected of Acute Abdomen in the Elderly. J Gastrointest Surg 2015;19(8):1407-1414. https://doi.org/10.1007/s11605-015-2830-3

12. Kärkkäinen JM, Acosta S. Acute mesenteric ischemia (part I) - Incidence, etiologies, and how to improve early diagnosis. Best Pract Res Clin Gastroenterol 2017;31(1):15-25. https://doi.org/10.1016/j.bpg.2016.10.018

13. Kanasaki S, Furukawa A, Fumoto K, et al. Acute Mesenteric Ischemia: Multidetector CT Findings and Endovascular Management. Radiographics 2018;38(3):945-961. https://doi.org/10.1148/rg.2018170163

14. Savlania A, Tripathi RK. Acute mesenteric ischemia: current multidisciplinary approach. J Cardiovasc Surg (Torino) 2017;58(2):339-350.

https://doi.org/10.23736/S0021-9509.16.09751-2

15. Gnanapandithan K, Feuerstadt P. Review Article: Mesenteric Ischemia. Curr Gastroenterol Rep 2020;22(4):17. https://doi.org/10.1007/s11894-020-0754-X

16. Memet O, Zhang L, Shen J. Serological biomarkers for acute mesenteric ischemia. Ann Transl Med 2019;7(16):394. https://doi.org/10.21037/atm.2019.07.51

17. Lawson RM. Mesenteric Ischemia. Crit Care Nurs Clin North Am 2018;30(1):29-39. https://doi.org/10.1016/j.cnc.2017.10.003

18. Copin P, Zins M, Nuzzo A, et al. Acute mesenteric ischemia: A critical role for the radiologist. Diagn Interv Imaging 2018;99(3):123-134. https://doi.org/10.1016/j.diii.2018.01.004

19. Garzelli L, Nuzzo A, Copin P, et al. Contrast-Enhanced CT for the Diagnosis of Acute Mesenteric Ischemia. AJR Am J Roentgenol 2020;215(1):29-38. https://doi.org/10.2214/AJR.19.22625

20. Acosta S, Kärkkäinen J. Open abdomen in acute mesenteric ischemia. Anaesthesiol Intensive Ther 2019;51(2):159-162. https://doi.org/10.5114/ait.2019.86280

21. Bala M, Kashuk J, Moore EE, et al. Acute mesenteric ischemia: guidelines of the World Society of Emergency Surgery. World J Emerg Surg 2017;12:38. https://doi.org/10.1186/s13017-017-0150-5

22. Kühn F, Schiergens TS, Klar E. Acute Mesenteric Ischemia. Visc Med 2020;36(4):256-262.

https://doi.org/10.1159/000508739 


\section{4}

ŪMINIS A. MESENTERICA KRAUJOTAKOS

NEPAKANKAMUMAS: KLINIKINIS ATVEJIS

D. Bajoriūnaitė, J. Balčiūnas, D. Vaiciukevičius, M. Jasinskaitė, A. Montvila

Raktažodžiai: a mesenterica kraujotakos nepakankamumas, viršutiné pasaito arterija, žarnyno išemija, mezenterinè trombozè.

Santrauka

Pristatomas 74 metų paciento, kuris skundèsi prieš 4 valandas prasidejusiu ūmiu krūtinès skausmu ir spaudimu, juodomis išmatomis, atvejis. Anamnezejje - prostatos hiperplazija ir aortos operacija, kuri komplikavosi žarnyno nekroze. Atlikta kompiuterinė tomografija (KT) parode kraujavimą ị dvylikapirštę žarną, kuris buvo sustabdytas naudojant adrenaliną. Sustabdžius kraujavimą, atlikta vainikinių arterijų angiografija. Pacientas pradejo skųstis stipriu pilvo skausmu. Pilvo ir dubens kontrastinè KT parode viršutinès pasaito arterijos (VPA) trombozę. Pacientui buvo atlikta plonosios žarnos rezekcija, ileostomija, cistostomija. Atliktas histopatologinis tyrimas parode išeminius ir nekrozinius pokyčius. Nepaisant taikyto gydymo, pacientas mirè. Gydytojai turètų ịvertinti VPA trombozès riziką, kaip galimą pilvo skausmo priežastį, ypač vyresnio amžiaus ir širdies ir kraujagyslių ligomis sergantiems pacientams. Kontrastinès kompiuterinès tomografijos tyrimas turètų būti pirmojo pasirinkimo metodas, esant neaiškiai diagnostikai. Tinkamas simptomų ir rizikos ịvertinimas, tikslus diagnostikos ir intervencinių priemonių naudojimas gali sumažinti aukštą mirtingumą ir padèti diagnozuoti šią patologiją.

Adresas susirašinėti: justbalciunas@gmail.com

Gauta 2021-05-25 